\title{
CORPORATE LIFE CYCLE METHODS IN EMERGING MARKETS: EVIDENCE FROM TURKEY
}

\section{DOI: 10.17261/Pressacademia.2017.690}

JEFA- V.4-ISS.3-2017(2)-p.224-236

Omer Faruk Gulec ${ }^{1}$, Semra Karacaer ${ }^{2}$

${ }^{1}$ Kırklareli University, Department of Management, Kırklareli, Turkey. omerfarukgulec@gmail.com

${ }^{2}$ Hacettepe University, Department of Management, Ankara, Turkey. semra@hacettepe.edu.tr

\section{To cite this document}

Gulec, O.F. and Karacaer, S., (2017). Corporate life cycle methods in emerging markets: evidence from Turkey. Journal of Economics, Finance and Accounting (JEFA), V.4, Iss.3, p.224-236.

Permanent link to this document: http://doi.org/10.17261/Pressacademia.2017.690

Copyright: Published by PressAcademia and limited licenced re-use rights only.

\begin{abstract}
Purpose - This paper focuses on the corporate life cycle concept which is one of the vital theories to analyze the firms more homogeneously. The aim of this study is to elaborate main life cycle classification procedures and to compare the most cited methodologies regarding financial indicators according to the expectations from the stages.

Methodology - We review the literature and especially examine three firm life cycle methods; Anthony and Ramesh (1992), Yonpae and Chen (2006) and Dickinson (2011). We also develop five hypotheses that are related to firm size, profitability, stock returns, liquidity and risk of the firms for three different stages through using descriptive statistics and test.

Findings - According to the results, while growth firms have higher risk, mature firms are more profitable and get higher stock returns. On the other hand, decline firms are bigger and more liquid than the other stages. The findings also suggest that Anthony and Ramesh (1992) life cycle classification procedure provides a little better insight than the other methods.

Conclusion - The study defines the firm life cycle notion which is an expanded version of product life cycle through explaining the most common classification procedures. Investors should concentrate on firms that are at growth stage since they have more potential to receive profitable projects. However, mature firms are at the peak point of the profitability and the risk is relatively low. Firms at the decline stage are one of the biggest candidates of stagnation and the capacity cannot be fully utilized.
\end{abstract}

Keywords: Corporate life cycle, accounting performance, financial ratios, life cycle stages.

JEL Codes: M40, M41, M49

\section{INTRODUCTION}

The primary objective of financial reporting is to provide accurate, reliable and timely information and to communicate briefly about financial positions and activities with the interested parties. Financial statement users use the necessary information to invest in business, to provide credit or to fulfill other purposes. It is a most known fact that firm values are not same or even differ significantly, although some of the firms have similar financial results and the same field of activity. Previous studies prove that accounting procedures which are applied and economic conditions specific to the firm play a major role in determining the firm value.

Corporate life cycle theory is one of the key analysis to examine the economic conditions which is unique to the company since the 1970s. It has frequently been used in academic research in recent years to highlight the concept that firms at each of the life-cycle stages have different characteristics that affect the usefulness of accounting measures of performance and firm value. The theory of corporate life-cycle has been widely studied in a variety of disciplines, such as microeconomics (Mueller, 1972), management (Miller \& Friesen, 1984) and accounting and finance (Aharony et al., 2006; Anthony \& Ramesh, 1992; Black, 1998b; DeAngelo et al., 2006). Even though there is no consensus on the definition of the corporate life cycle, the most common definition is as follows. "Firm life cycles are distinct and identifiable phases that result from changes in internal factors (e.g., strategy choice, financial resources, and managerial ability) and external factors (e.g., competitive environment, macroeconomic factors) many of which arise from strategic activities undertaken by the firm.", 
(Adizes, 1979; Miller \& Friesen, 1983). Thus, the corporate life cycle is the integrated result of firm strategies and allocation of resources, extensively reflecting a firm's innate factors (Dickinson, 2011).

The firm life cycle stages can be treated as an expanded version of the product life cycle concept in marketing and microeconomics (Mueller, 1972; Rink \& Swan, 1979). Firms can be described regarding life cycle stages that depend on the strategies, organizational structure and the uncertainty that they face during a particular period in its life similar to an individual product (Jaafar \& Halim, 2015). The concept of corporate life cycle which is derived from microeconomics and marketing shows various differences from product life cycle. Firstly, corporate life cycle theory is a multidimensional approach due to a large number of models developed based on the business decision-making processes, strategic preferences, leadership structures and many financial and non-financial determinants of the firms.

Another point that differs from the product life cycle concept is the number of stages. Although the number of stages is a controversial issue and shows a wide variation in many models, the number of studies based on 3 to 5 stages is superior in accounting and finance literature. Last but the most important difference is the path (route) that is followed by the companies during the life cycle process. Companies are evolving entities and the rate of their evolution are jointly determined by internal and external factors (Dickinson, 2011). Even though firms generally follow a predictable and consistent scheme as startup, growth, mature and decline as in product life cycle, the stages of the firms are not supposed to follow a particular direction in corporate life cycle theory. Firms move through these phases as the result of the competition environment, uncertainty and any managerial and financial decision. Firms may stay at a stage for a long time, and they may pass through the first stages even they are at last stages or they may be exposed to deaths very quickly. Thus, this non-deterministic analysis can be regarded as an advantage in terms of its ability to reflect the representation of the dynamic structure of the enterprises. Also, it provides a dynamic analysis framework for interpreting financial and accounting policy choices from a multi-period dynamic perspective (Chen et al., 2010). Determination of a firm's stage accurately will aid to analyze not only the current situation, but it will also help to plan the future. Moreover, it will be possible to improve existing and potential partnerships by providing better recognition and evaluation of the company. It is also crucial for mutual funds to detect the life cycle stages of firms since mutual funds generally invest in the firms which are at startup or growth phases.

Recently, many accounting and finance studies use firm life cycle hypothesis to categorize and define companies more homogeneously in their analysis. Some of these studies aim to reveal a better life cycle model and identify variables specific to business and/or sectors so that firms could be classified more accurately into different stages. On the other hand, in other studies, life cycle analysis is considered as a mediator variable to examine the effects on the explanatory power of the other topics in the accounting and finance literature.

The main motivation for this study is to explain the material classification procedures and to compare the most cited methodologies according to the expectations from the stages. Thus, main financial ratios and accounting values such as firm size, profitability, liquidity etc. are examined in the light of corporate life cycle concept through applying different classification techniques. According to the results, Dickinson (2011) method offers a parsimonious way to classify the firmyear observations and therefore, findings vary substantially from the other methods that are Anthony and Ramesh (1992) and Yonpae and Chen (2006). Latter methods suggest better results according to the hypothesis developed related to firm size, profitability, liquidity etc.

The remainder of this paper is organized as follows. Section 2 gives a brief overview of the corporate life cycle concept and describes the characteristics of stages. Section 3 discusses the material classification procedures. Section 4 examines the research design, the data and empirical findings and the paper concludes in section 5 .

\section{CORPORATE LIFE CYCLE STAGES}

The firm life cycle theory is a widely studied concept which mainly concentrates on the accounting performance of firms at different stages. Firm-years observations in the life cycle theory are relatively more homogeneous than the other procedures. The theory of life cycle is based on the hypothesis that firms will exhibit different characteristics at different stages and hence different strategies and performance criteria will be applied at various stages (Kallunki \& Silvola, 2008). Accounting performance measures differ across life cycle stages, which is handled in the management accounting literature (Richardson \& Gordon, 1980).

Related research divides a firm's life cycle into periods which are distinguished by firm-specific characteristics such as the degree of uncertainty, assets in place and investment opportunities (Aharony et al., 2006). Capturing life cycle at the firm level (rather than at the individual product or industry level) is a difficult undertaking since it is a composite of many overlapping, but distinct product life cycle stages (Dickinson, 2011). Consequently, this will affect the number of stages proposed in the life cycle models. Studies have to deal with issues in determining which model is superior or what number should be for the stages that best reflect the evolution or development of a firm (Jaafar \& Halim, 2015). Even though studies suggest a different number of stages from three to ten, all firms evolve through the same series of stages. Adizes 
(1979) is the first study that suggests ten life cycle stages which are the maximum among the other studies. Dickinson (2011) and Gort and Klepper (1982) define five life cycle stages. These are

Introductory stage, where an innovation is first offered;

a growth stage, where the competition rises dramatically;

a maturity stage, where the number of producers and imitators reach a maximum level;

a shake-out stage, where the market share begins to decline;

and a decline stage, where entrance to the market reaches almost to zero.

Black (1998a, 1998b) suggests four stages except for shakeout stage. (Aharony et al., 2006; Anthony \& Ramesh, 1992; Yonpae \& Chen, 2006) are the studies that suggest three stages as growth, mature and decline. In this study, start-up, growth, mature and decline stages will be explained and three of them (except for start-up stage) will be handled in the analysis.

\subsection{Start-up (Introductory) Stage}

Startup stage is a phase for the young and dynamic firms that are generally in the establishment process. In many studies, initial public offerings represent the first significant stage in the evolution of a public company and they are mainly considered as a startup company due to the lack of past public information (Jain \& Kini, 1999). Firms allocate their resources on developing new service and products to gain comparative advantage at the other stages. The firm risk is the highest at this stage since firms are in the process of development with regards to many financial indicators and uncertainty is at a maximum level about the future of the company. Firms have smaller values regarding total assets, total sales, and market value. In addition, it is expected to publish low tangible and intangible assets and low positive operational cash flow from the firms at this stage (Black, 1998a). Net income, operational profitability, return on assets and earnings per share is quite small as well (Black, 1998b).

At the start-up stage, the firm's production focuses on a new product or products. Firms have few assets with low collateral value and experience high business risk and high borrowing and equity cost (Aharony et al., 2006). Therefore, young firms face with lots of investment opportunities but little earnings issue stock (Seifert \& Gonenc, 2012). Evidence from prior research proves that small firms, which are likely to be at start-up or growth stages, tend to report losses than are larger firms (Hayn, 1995). Stock returns and value relevance of accounting information will be lower (Anthony \& Ramesh, 1992). Low dividend payout is usually associated with early life-cycle stages because firms need cash to prevail in the market and generated cash will be allocated to the new projects to provide growth opportunity instead of dividend distribution. According to Myers (1977), the components of firm value are assets in place and growth opportunities. Moreover, the proportion of these two elements differs at each of the firm life-cycle stages. Because growth opportunity is the important part of the value of a company at this stage, firms will be in need of financing to invest in projects that have positive net present value.

\subsection{Growth Stage}

At the growth stage, relatively younger firms usually have new products and technology. Cash flows from operations and earnings will be gradually positive when firms survive at the startup stage and continue to grow. Expected profits from investment opportunities increase and the need for financing will become even more felt. Despite the decrease in uncertainty, the cost of borrowing is still high and shareholders would prefer to reinvest earnings (Aharony et al., 2006). Since managers will use the generated cash to evaluate growth opportunities more effectively, the distribution of dividends will be zero or close to zero as at startup stage (Black, 1998b). In determining the value of the firm, growth opportunities still remain an important factor.

The first stages of the firm life cycle generally result in negativity or even bankruptcy for many firms due to cash flow and financing problems. Gaver and Gaver (1993) declare that lower leverage, lower dividend and more stock-based incentive compensation are specific to the growth firms. Sales growth rates and investment amounts to tangible fixed assets are significantly higher. Thus, capital expenditures growth is also going to be higher for the growth companies. In the light of all these information, firms with the highest sales growth rate and capital expenditures and lowest dividend payments and the lowest age are treated as the biggest candidates of the growth period.

\subsection{Mature Stage}

Firms exhibit lower or moderate growth rates in sales and financing needs are supplied through internal sources. Assets in place are higher than the growth opportunities for detecting the firm value. At the maturity stage, production assets are more fully utilized since the economies of scale fully achieved. While a number of producers and competition increase, market share gradually decreases. Investment projects with positive net present value relatively reduce as the competition increases and the products of the companies reach sufficient saturation on the market. Thus, it would be contrary to the 
interests of the company's shareholders to follow a policy to use the profits gained to invest again. Instead, they would prefer managers who pay dividends more (Aharony et al., 2006). However, managers may use the resources to expand the business in order to raise their own welfare contrary to the expectations of the shareholders (Grabowski \& Mueller, 1975; Mueller, 1972). For all these reasons, investors want to follow company managers and firms more closely that is known from agency theory.

Mature firms with fewer investment opportunities but greater cash flows tend to finance internally and distribute funds as dividends and/or repurchases since the companies can provide a significant amount of liquidity from past investments (Seifert \& Gonenc, 2012). Uncertainty and the cost of borrowing decline due to the increase in the collateralized assets, earnings and cash flows. Depreciation amounts are at a level to finance asset replacements and maintenance. Firms with a moderate sales growth rate and capital expenditures and average dividend payments are considered as the biggest candidates of the maturity period.

\subsection{Decline Stage}

Market competition is extremely high while market share falls and expansion strategy offers less profit potential. Due to the changes in technology or consumer expectations and increasing competition may cause to decrease in the market share. This stage can often be described as a period when sales and earnings fall and production capacity cannot be fully utilized (Black, 1998a). Because of the decrease in the demand for the products of the firms, profitability and dividend distribution are also adversely affected. While earnings volatility is relatively higher, earnings persistence is quite low.

Firms that are at the decline stage may not necessarily have an end such as bankruptcy or any failure. Companies can transfer new technologies and regenerate by investing in new product lines and move back into the growth or mature stage and forestall failure for many years (Aharony et al., 2006). As it is mentioned in agency theory, managers may invest in new and high-risk investment project with fear of losing their existing business. External sources with higher cost may also be preferred to finance these risky projects. However, a negative view to the company may lead to the borrowing at a higher cost or to the detention of projects that provide growth opportunities. Nevertheless, firms face less risk and less borrowing costs than the introductory stages, since collateralized assets for external financing is relatively higher. Companies with the lowest sales growth rate and capital expenditures and highest dividend payments and highest age will be at the decline period. Figure 1 shows the life cycle phases and the functional areas for a company.

\section{Figure 1: The Corporate Life Cycle and Functional Areas of Corporate Activity}

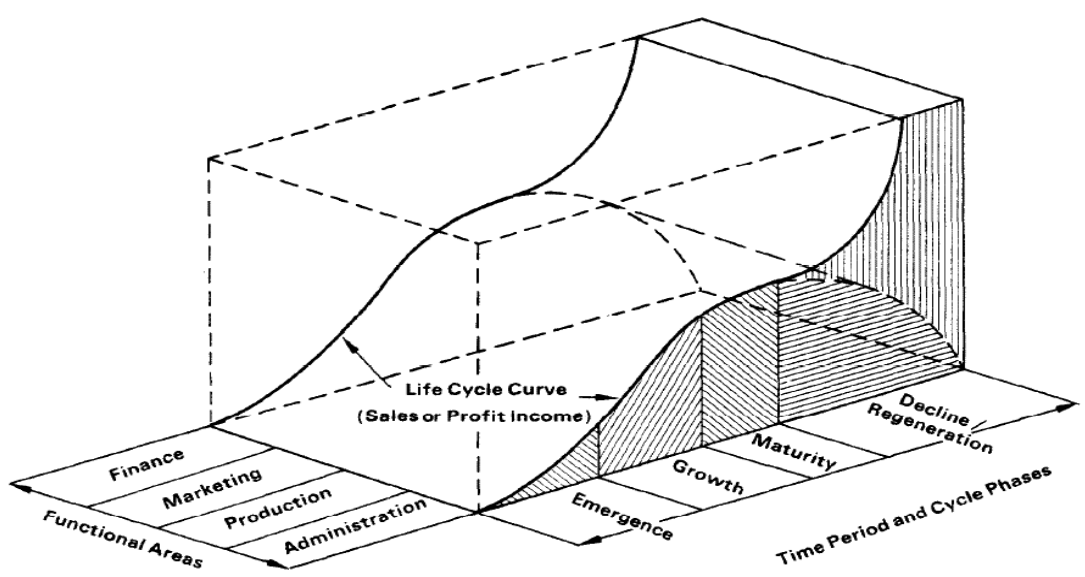

Source: James (1974)

\section{COMMON LIFE CYCLE METHODS}

There are various classification methods based on many variables specific to firms or sectors to determine the stages of firm life cycle. In these studies, variables such as sales growth or firm age are commonly used for many methods, but some studies have used different variables in determining life cycle stages. Cash flow statement components, retained earnings or number of employees are some examples of the different classification strategies in literature. In this section, studies that are leading the other studies with the most used methods for determining the life cycle stages are examined. 


\subsection{Anthony and Ramesh (1992) Classification Method}

Anthony and Ramesh (1992) is one of the first studies that examine the life cycle concept quantitatively and within a systematic way. Firm-year observations are classified into life cycle stages according to univariate and multivariate ranking procedures. In the study, each firm-year observation needs to be classified independently of each other is one of the major difference from the product life cycle. Four classification variables have been identified; Annual dividend payout ratio (DP), sales growth (SG), capital expenditure (CEV) and firm age (AGE). When determining the classification variables, it refers to studies on similar topics in marketing, economics, and management accounting literature (Kotler, 2009; Spence, 1979). Expectations regarding life cycle variables are given in Table 1.

Table 1. Life Cycle Descriptors

\begin{tabular}{|c|c|c|c|c|}
\hline Life Cycle Stages & Dividend & Sales Growth & Capital Expenditure & Firm Age \\
\hline Growth & Low & High & High & Young \\
\hline Mature & Medium & Medium & Medium & Mature \\
\hline Decline & High & Low & Low & Old \\
\hline
\end{tabular}

Firms that are at the first stages generally follow a policy of not paying dividends or paying low dividends as they invest in projects that have positive net present value. Also, due to the investments in these projects, it leads to higher capital expenditures and higher sales growth. Thus, according to methodology given in Table 1, firms with the highest (lowest) sales growth rate and capital expenditures and lowest (highest) dividend payments and age are treated as the biggest candidates of the growth (decline) period.

\section{Measurement of Life Cycle Variables}

They compute the life cycle variables as follows:

1) $D P_{t}=\left(D_{I V} / / I B E D_{t}\right) \times 100$

2) $\mathrm{SG}_{\mathrm{t}}=\left(\right.$ Sales $_{\mathrm{t}}-$ Sales $\left._{\mathrm{t}-1}\right) /\left(\right.$ Sales $\left._{\mathrm{t}-1}\right) \times 100$

3) $\mathrm{CEV}_{\mathrm{t}}=\left(\mathrm{CE}_{\mathrm{t}} /\right.$ Value $\left._{\mathrm{t}}\right) \times 100$

4) $A G E=$ Current Year - Establishment Year

$\mathrm{DIV}_{\mathrm{t}}=$ Annual Dividend Payment

$\mathrm{IBED}_{\mathrm{t}}=$ Income Before Extraordinary Items and Discontinued Operations in Year $\mathrm{t}$

SALES $_{\mathrm{t}}=$ Net Sales in Year $\mathrm{t}$

$\mathrm{CE}_{\mathrm{t}}=$ Capital Expenditures in Year $\mathrm{t}$

VALUE $_{t}=$ Market Value of Equity Plus Book Value of Long-Term Debt at the End of Year $t$

The firm age variable that is a non-financial control variable is included to reduce the risk of potential correlations between variables and to avoid omitted variable in determining life cycle stages. In the study, the median values of the variables for the past five years DP, SG, and CEV have been calculated (denoted as MDP, MSG, and MCEV). This calculation requires at least six years of data availability for each firm. Firm year observations are assigned to different life cycle stages according to univariate or multivariate classification criteria.

Table 2: Anthony and Ramesh (1992) Composite score

\begin{tabular}{|c|c|c|c|}
\hline Life Cycle Stages & Dividend & Sales Growth & Firm Age \\
\hline Growth & 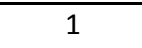 & 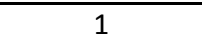 & 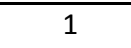 \\
\hline Mature & 2 & 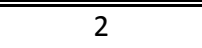 & 2 \\
\hline Decline & 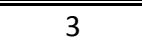 & 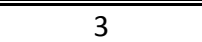 & 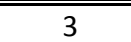 \\
\hline
\end{tabular}


According to the multivariate classification methodology, total scores have been obtained by assigning a firm-year observation 1, 2, 3, if it takes place at growth, mature, decline respectively. For example, while a firm -year observation with a low sales growth rate (SGR) is assigned a score of 3 and will be a candidate for growth stage, a firm -year observation with a low dividend payout (DP) is assigned a score of 1 and will be classified to decline stage.

Anthony and Ramesh (1992) argue that using a composite score technique may cause to neglect some interactions between the variables. For instance, low dividend distribution can be explained as either saving the cash for the profitable investments, or it would be the cash flow problems of the firm. However, they claim that classification will be handled properly with the help of remaining variables. Therefore, multivariate ranking procedure is superior to the univariate procedure with regards to evaluating firm-year observations in detail. While capital expenditure is included in the univariate classification, it has not been involved in the multivariate ranking procedure, since it gives a little insight on life cycle stage.

\subsection{Classification Methodologies Similar to Anthony and Ramesh (1992) Method}

There are various methods similar to Anthony and Ramesh (1992) methodology many of which concentrate on to improve the model through suggesting minor changes.

Yonpae and Chen (2006) is one of the similar studies that basically used Anthony and Ramesh (1992) variables but developed a 5-point scoring system. Although it is similar to the 3-point ranking procedure, the main difference arises from the controversial issue about dividend distribution variable and they focus on to eliminate this deficiency. In addition, Yonpae and Chen (2006) emphasize the superiority of multivariate ranking and mentioned about the drawbacks of the univariate classification method. Lastly, capital expenditure is included in the multivariate classification since they argue that it is a significant component in determining the life cycle stages properly. Scoring system is provided in Table 3.

Table 3: Yonpae and Chen (2006) Composite Scoring

\begin{tabular}{|c|c|c|c|c|}
\hline Quintiles & Dividend Ratio & Sales Growth & "Capital Expenditure & Firm Age \\
\hline \%80 - \%100 & 3 & $\overline{25}$ & 5 & 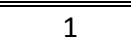 \\
\hline \%60 - \%80 & 3 & 4 & 4 & 2 \\
\hline \%40 - \%60 & 3 & 3 & 3 & 3 \\
\hline \%20 - \%40 & 4 4(2)* $^{*}$ & 2 & 2 & 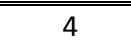 \\
\hline \%0 - \%20 & $5(1)^{*}$ & 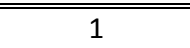 & 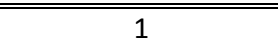 & $\overline{25}$ \\
\hline
\end{tabular}

There are two possible assessments of a business that distributes a low dividend or no dividends. First of all, the business may not distribute dividends to invest in projects with positive net present value or to evaluate growth opportunities. In the first scenario, it is very likely that the firm will be at the growth stage through considering the other classification variables. On the other hand, a firm that experiences cash flow problems or liquidity will not be able to distribute dividends and will be more likely to be involved at the decline stage. Thus, if the total score of sales growth, capital expenditure, and firm age is below or equal to 7, firm-year observations for the dividend ratio with the score of 4 or 5 will be replaced to 2 or 1 respectively. This correction will allow the better classification in terms of dividend ratio.

The composite scoring system is as follows:

The firm-year observations with a total score of 16-20 points, growth stage

The firm-year observations with a total score of 9-15 points, mature stage

The firm-year observations with a total score of 4-8 points, decline stage

Aharony et al. (2006) is another study that have also identified the same life cycle descriptors (sales growth, capital expenditure, dividend payout, and firm age). However, there are some changes in the calculation and standardization of variables. Measurement of life cycle variables is as follows:

\section{1) Sales Growth $\quad\left(\right.$ Sales $_{t} /$ Sales $\left._{t-2}\right)$}

While previous studies prefer to use the difference between the current year sales and previous year sales, they suggest that using the two-year difference. Because this will aid to mitigate the effects of extraordinary operations such as mergers or acquisitions.

\section{2) Capital Expenditures}

(Capital Expenditures + Research and Development Expense) ${ }_{t} /$ Total Assets $_{t}$ 
It has been emphasized that research and development expense is a proxy for investment in intangible assets and should also be added to capital expenditures

\section{3) Dividend Payout}

(Sale of Common and Preferred Stock - Purchase of Common and Preferred Stock - Cash Dividend) ${ }_{t} /$ Total Assets $_{t}$

Aharony et al. (2006) also examine the negative dividend situation by calculating the purchase and sales of stocks instead of only using annual dividend distribution in the previous studies

\section{4) Firm Age}

(Difference between the first date that firms' data is available in the database and the current year)

Deflator which is used to minimize the size differences between the firms is another major difference in this study. While previous studies prefer to use the market value of equity plus book value of long-term debt as a deflator, this study uses total assets in year $t$ as a deflator. Aharony et al. (2006) follow the standardization methodology of four life cycle variables by subtracting their sample mean and dividing by their standard deviation. Firm-year observations that are obtained from combined clustering measure are ranked in ascending order and five quintiles have been identified. While the first, the third, and the fifth quintiles represent the firms at the growth, mature, and decline stages respectively, the second and the fourth quintiles are not included to present a solid classification.

Liu (2006) has adopted a classification procedure consisting of some firm-specific variables and cash flow profiles to identify the stages properly. All variables are deflated by total assets. In addition to other variables that identified in previous studies, Liu (2006) suggest the cost of goods sold as a determinant of life cycle stage. He argues that a company can either increase its profits by increasing its operations or by reducing its costs. Firms that are at the growth stage deal with higher production costs compared to other stages. However, at the maturity stage, a firm can maintain its competitive position at low-cost levels by specializing in production. Moreover, fixed costs vary considerably with respect to the production level at different stages, while variable costs remain relatively stable. Except for the cost of goods sold and cash flow profiles of firms, the classification methodology is quite similar to previous studies, and it is as follows:

Table 4: Composite Scores Liu (2006)

\begin{tabular}{|c|c|c|c|c|}
\hline & \\
\hline & $1,2,3 \ldots$ & $49,50,51 \ldots$ & $98,99,100$ & $\%$ \\
\hline Capital Expenditures & High & Medium & Low & $20 \%$ \\
\hline Changes in Revenues & Positive & Zero & Negative & $20 \%$ \\
\hline Cost of Goods Sold & High & Medium & Low & $20 \%$ \\
\hline Firm Age & Low & Medium & High & $20 \%$ \\
\hline \multirow{2}{*}{ Cash Flow Profile } & CFO $<0$ & $\mathrm{CFO}>0$ & $\mathrm{CFO}<0$ & \multirow{2}{*}{$20 \%$} \\
\hline & $\mathrm{CFF}>0$ & & $\mathrm{CFF}<0$ & \\
\hline
\end{tabular}

\begin{tabular}{|c|c|c|c|c|c|}
\hline Ranking Score & $1-20$ & $21-40$ & $41-60$ & $61-80$ & $81-100$ \\
\hline L.C. Stages & Rapid Growth & Slow Growth & Maturity & Early Decline & Late Decline \\
\hline
\end{tabular}

DeAngelo et al. (2006) use the term of earned/contributed a capital mix to identify the life cycle stages with regards to the dividend distribution of firms. Dividend distribution is a strategy of firms having high profitability, less attractive investment options and that are generally at maturity stage. As stated in Fama and French (2001), the dividend distribution decision is only the optimal strategy of firms with high profitability and low growth rate. They determine the life cycle stages through assessing the probability of a firm's pay dividends with the variables of retained earnings to total equity (RE/TE, earned capital mix) and total assets (RE/TA, contributed capital mix). They argue that while firms with relatively high (RE/TE) and (RE/TA) are more likely to pay dividends, firms with low (RE/TE) and (RE/TA) tend to be at the capital infusion stage.

Jaafar and Halim (2015) is another study that follow the similar procedure for life cycle classification except for the variable of market value/book value. They claim that this ratio represents the mix between growth opportunities and firm's assets in place as a proxy of life cycle stages. In other words, firms having higher MV/BV display more investments to the projects with positive net present value and are more likely to be at the growth stage. Won and Ryu (2015) is the last study that offers composite score methodology but with a distinct variable which is the change in the number of the employee. 


\subsection{Dickinson (2011) Classification Methodology}

Dickinson (2011) examines the validity of the cash flow pattern as a representative of life cycle stages. It has been claimed that despite the parsimonious methodology the study follows, she argues that analyzing cash flow profiles is superior to univariate or multivariate classification procedures regarding objectivity. Lev and Zarowin (1999) states that the value relevance of earnings has lost its validity and the rate of change in the businesses has increased over time. They also indicate that cash flow components will better reflect the profitability of the firm, growth opportunities, and risk. Consequently, Dickinson (2011) points out that it would be beneficial for all stakeholders to try to determine the life cycle stages of firms using criteria other than earnings or any subjective variables. This study tries to develop a valid, reliable and a parsimonious model that takes into account the characteristics of the company's cash flows (CFI, CFF, and CFO).

The advantages of methodology to the other models are emphasized as follows.

- To be able to forecast the future profitability and growth rates better

- To be able to express better the importance of economics doctrines in determining the future profitability of firms

- To be able to identify potential market risk factors and/or mispricing depending on the differences in life cycle stages

- While a classification through using cash flow patterns is the organic results of a firm, other procedures will have a uniform distribution

- In this dynamic procedure, life cycle stages does not follow a routine process and a certain order

In a combination of the signs of all three cash flow components, eight possible $\left(2^{3}=8\right)$ patterns have been obtained. Dickinson (2011) predicts the signs of each cash flow from the economics literature and classify the firm-year observations according to the signs provided in Table 5.

Table 5: Dickinson (2011) Cash Flow Profiles

\begin{tabular}{|c|c|c|c|c|c|c|c|c|}
\hline Cash Flows Components & 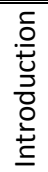 & 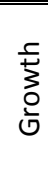 & 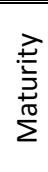 & 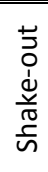 & 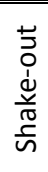 & 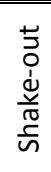 & 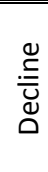 & $\frac{\stackrel{\Xi}{\bar{U}}}{\stackrel{\Xi}{\Delta}}$ \\
\hline $\begin{array}{c}\text { Cash Flows From } \\
\text { Operating Activities (CFO) }\end{array}$ & - & + & + & - & + & + & - & - \\
\hline $\begin{array}{c}\text { Cash Flows From Investing } \\
\text { Activities (CFI) }\end{array}$ & - & - & - & - & + & + & + & + \\
\hline $\begin{array}{c}\text { Cash Flows From } \\
\text { Financing Activities (CFF) }\end{array}$ & + & + & - & - & + & - & + & - \\
\hline
\end{tabular}

\section{RESEARCH DESIGN}

\subsection{Sample Selection}

This study covers non-financial companies operating continuously in the Istanbul Stock Exchange between 2006 and 2014. Since the financial statements of financial companies are subject to different regulations and principles, the companies in these sectors are excluded from the analysis. The financial statements of 35 companies are excluded from the analysis because they are not included in this date range or because their data can not be accessed for various reasons. It has also been decided to expel 4 firms as a result of $\% 1$ outlier analysis of the upper and lower values. The data used in the analysis have been obtained from the Thomson Reuters Eikon Database, Public Disclosure Platform and Borsa Istanbul website.

Table 6: Sample Firms

\begin{tabular}{|lc|}
\hline Non-Financial Firms Listed on BIST & 192 \\
Firms Have Missing Data and Outliers & 39 \\
Firms Available For Analysis & 153 \\
Total firm-year observations & 1373 \\
\hline
\end{tabular}




\subsection{Hypothesis Development}

The firm life cycle analysis is a dynamic process that is shaped by many internal and external factors of a firm and is influenced by various financial or non-financial characteristics of the firm. How this dynamic process affects different financial items and how these financial indicators have a pattern at stages have been the subject of many studies. For this reason, we have examined the main financial ratios and accounting items according to the three different life cycle classification procedures. These methods are Anthony and Ramesh (1992), (1. method) and Yonpae and Chen (2006), (2. method) and Dickinson (2011), (3. method) as mentioned in the previous section. Dickinson (2011) classification procedure includes five stages; introduction, growth, mature, shake-out and decline. In order to analyze the stages uniformly, introduction and shake-out stages are expelled from the analysis. Therefore, it leaves us 1085 firm-year observations for this method while the other methods consist of 1373 firm-year observations. It has been aimed to obtain a more accurate pattern by including the median values in addition to the mean values of the relevant financial variables in the analysis. We have also examined the values with $T$ test to display whether the changes between stages are statistically significant. We have hypothesized five financial items and these are Firm Size (denoted by Total Assets), Profitability (denoted by Earnings per Share), Stock Return (denoted by Cumulative Return), Liquidity (denoted by Acid-Test Ratio) and Capital Structure (denoted by Financial Leverage).

The businesses at the decline stage are significantly different regarding their equities and assets from the growth period. Because decline stage is often considered as a period when businesses do not look for new investments and also growth opportunities are diminishing. For this reason, firms have only the options of conservation of the current position and development or liquidation, so the value of the firm is determined only by the assets in place. These firms have more assets than the firms at the other stages. Therefore, first hypothesis related to firm size is;

H1: Firms at the decline stage are bigger than the firms at the other stages.

Uncertainty and risk factors are considerably higher in start-up and growth firms due to the fact that they are usually new and small. Although sales growth is high, profitability level which is close to or above the break-even point is still unanswered question for the firms at initial phases. However, maturity stage is a stable and predictable period in which profitability levels reach maximum levels. Mature firms with fewer investment opportunities but greater cash flows and profitability levels tend to have higher share returns than the other firms at other stages. From this point of view, it is expected that the mean and median values of the profitability and stock return indicators will be higher for the firms at this phase.

H2: Firms at the mature stage are more profitable than the firms at the other stages.

H3: Firms at the mature stage get higher stock returns than the firms at the other stages.

Liquidity ratios are important for determining how successful an entity is in meeting its obligations with its assets. It is desirable that a non-financial firm generally has a current ratio of 2 and an acid-test ratio of about 1 in the accounting literature. Factors affecting the liquidity status of a business are not only the sector or operations of the firm but also the life cycle stage. At the growth stage, businesses are in need of cash to invest in profitable projects and to be able to evaluate the growth opportunities. Due to the high risk, they prefer foreign resources to meet their financing needs. However, as businesses mature, financing needs will be met by using internal resources, which will also reduce foreign resources. Decline stage is the most liquid stage since the borrowing is less and liquidation of tangible assets is higher. Using the resources to close the obligations is a main strategy for the decline firms which leads to minimum financial leverage levels as well. Since growth firms have few assets with low collateral value and experiences high business risk and high borrowing and equity cost, financial leverage is at the highest level.

H4: Firms at the decline stage are more liquid than the firms at the other stages.

H5: Firms at the growth stage have higher risk than the firms at the other stages.

\subsection{Research Findings}

The size indicators of firms at different life cycle stages will be different from each other. Firms at the start-up or growth stages are relatively small, young and generally do not have well-structured management in their field of activity. On the other hand, as businesses grow and develop, they will have an increase in their assets, equity, and in their market values. Total assets have been used to determine the firm size effect at different life cycle stages in the analysis. According to the Anthony and Ramesh (1992) and Yonpae and Chen (2006), highest values for the mean and median values of total assets are at decline stage. However, Dickinson (2011) remarks the opposite in Table 7 since she offers a cash flow signs to determine the life cycle stages, Thus, hypothesis 1 is accepted only for the first two methods. 
Table 7: Total Assets (Million TL)

\begin{tabular}{l|ccc|ccc|ccc}
\hline $\begin{array}{l}\text { Classification } \\
\text { Method }\end{array}$ & \multicolumn{3}{|c|}{$\begin{array}{c}\text { Anthony and Ramesh } \\
\text { (1992) }\end{array}$} & \multicolumn{3}{c|}{$\begin{array}{c}\text { Yonpae and Chen } \\
\text { (2006) }\end{array}$} & \multicolumn{3}{c}{$\begin{array}{c}\text { Dickinson } \\
\text { (2011) }\end{array}$} \\
\hline Stages & Obs. & Mean & Median & Obs. & Mean & Median & Obs. & Mean & Median \\
\hline Growth & 315 & 389.955 & 159.816 & 481 & 941.996 & 217.318 & 310 & 1.210 .702 & 304.074 \\
Mature & 674 & 1.149 .265 & 219.619 & 399 & 1.226 .639 & 254.412 & 551 & 1.622 .498 & 298.487 \\
Decline & 384 & 1.564 .659 & 417.348 & 493 & 1.127 .262 & 265.527 & 224 & 291.763 & 103.710 \\
\hline T Statistics & T val. & Sig (2 tailed) & T val. & Sig (2 tailed) & T val. & Sig (2 tailed) \\
Growth - Mature & $-2,724$ & $0,007 * * *$ & $-2,346$ & $0,019 * *$ & 1,109 & 0,268 \\
Growth - Decline & $-10,399$ & $0,000^{* * *}$ & $-1,000$ & 0,318 & 7,382 & $0,000 * * *$ \\
Mature - Decline & $-9,290$ & $0,000^{* * *}$ & 0,483 & 0,630 & 6,041 & $0,000^{* * *}$ \\
\hline
\end{tabular}

While the sales growth and the investments in tangible fixed assets are high for the firms at the growth period, there is a decrease towards to the other phases. Cash flows from operations, earnings and expected profits from investment opportunities will be gradually positive at the growth stage. At the maturity stage, production assets are more fully utilized and market share reaches sufficient saturation since the economies of scale fully achieved. Therefore, profitability is at the highest level at the maturity stage as mentioned in product life cycle in figure 1. Stock return is also highly correlated factor with profitability variable. Profitable firms will get higher stock returns since these firms receive more attention by many investors. While growth firms are relatively risky and decline firms are at the phase of uncertainty about the future of the business, mature firms are the biggest candidates of the investors' portfolios to guarantee their investments. When we examine the Table 8 for the profitability variable which is denoted by Earnings per Share, hypothesis 2 is only accepted for the Dickinson (2011) method. On the other hand, stock returns hypothesis which is measured by cumulative returns is accepted for Anthony and Ramesh (1992) and Dickinson (2011). Since cash flows and earnings are correlated variables, the results are more consistent in Dickinson (2011) method.

Figure 1: Product Life Cycle

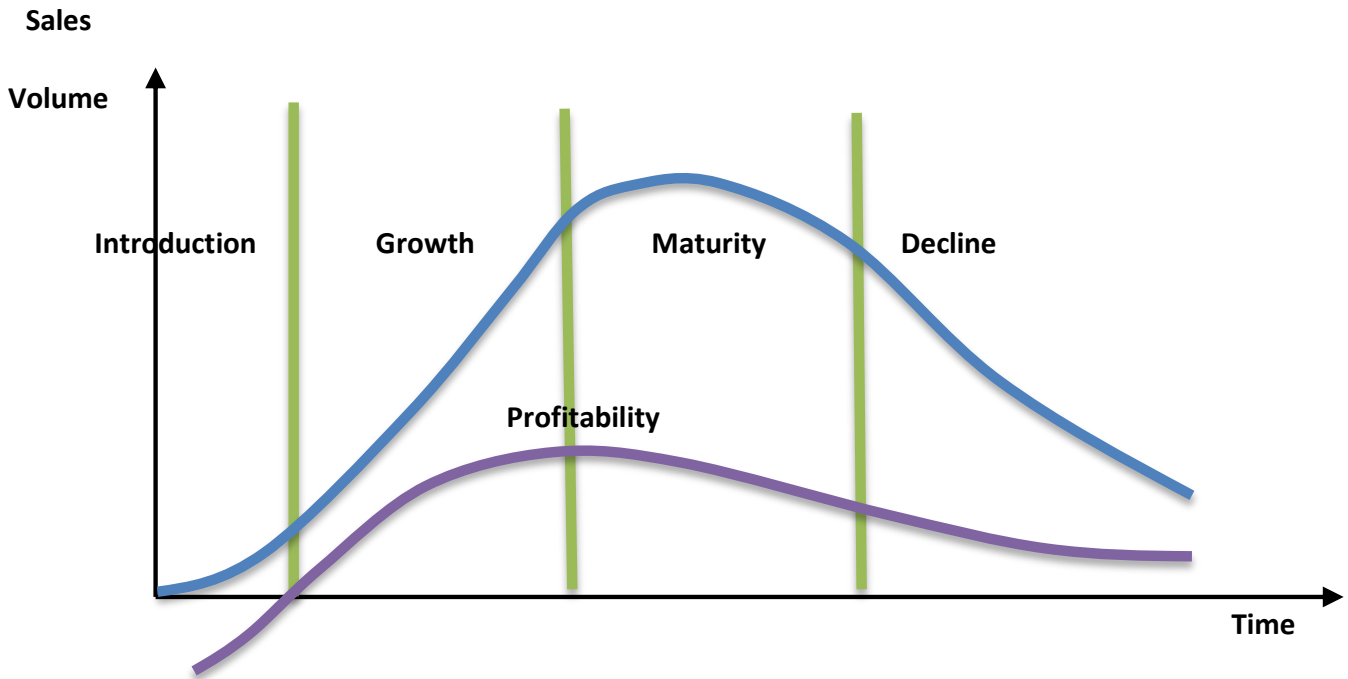

Table 8: Earnings per Share

\begin{tabular}{l|ccc|ccc|ccc}
\hline $\begin{array}{l}\text { Classification } \\
\text { Method }\end{array}$ & \multicolumn{2}{|c|}{$\begin{array}{c}\text { Anthony and Ramesh } \\
\text { (1992) }\end{array}$} & \multicolumn{3}{c|}{$\begin{array}{c}\text { Yonpae and Chen } \\
\text { (2006) }\end{array}$} & \multicolumn{3}{c}{$\begin{array}{c}\text { Dickinson } \\
\text { (2011) }\end{array}$} \\
\hline Stages & Obs. & Mean & Median & Obs. & Mean & Median & Obs. & Mean & Median \\
\hline Growth & 315 & 0,15 & 0,07 & 481 & 0,16 & 0,10 & 310 & 0,37 & 0,13 \\
Mature & 674 & 0,35 & 0,11 & 399 & 0,35 & 0,13 & 551 & 0,77 & 0,26
\end{tabular}




\begin{tabular}{|c|c|c|c|c|c|c|}
\hline Decline & 384 & 0,36 & 493 & 0,79 & 224 & 0,09 \\
\hline T Statistics & T val. & Sig (2 tailed) & T val. & Sig (2 tailed) & T val. & Sig (2 tailed) \\
\hline Growth - Mature & $-2,266$ & $0,024 * *$ & $-1,895$ & $0,059 *$ & $-2,337$ & $0,020 * *$ \\
\hline Growth - Decline & $-5,116$ & $0,000 * * *$ & $-6,081$ & $0,000 * * *$ & 2,131 & $0,036 * *$ \\
\hline Mature - Decline & $-3,573$ & $0,000 * * *$ & $-3,349$ & $0,001 * * *$ & 3,821 & $0,000 * * *$ \\
\hline
\end{tabular}

Table 9: Cumulative Returns

\begin{tabular}{|c|c|c|c|c|c|c|c|c|c|}
\hline \multirow{2}{*}{$\begin{array}{l}\text { Classification } \\
\text { Method }\end{array}$} & \multicolumn{3}{|c|}{$\begin{array}{c}\text { Anthony and Ramesh } \\
\text { (1992) }\end{array}$} & \multicolumn{3}{|c|}{$\begin{array}{c}\text { Yonpae and Chen } \\
\text { (2006) }\end{array}$} & \multicolumn{3}{|c|}{$\begin{array}{l}\text { Dickinson } \\
\text { (2011) }\end{array}$} \\
\hline & Obs. & Mean & Median & Obs. & Mean & Median & Obs. & Mean & Median \\
\hline Growth & 315 & $15,51 \%$ & $8,39 \%$ & 481 & $13,24 \%$ & $4,42 \%$ & 310 & $16,10 \%$ & $7,68 \%$ \\
\hline Mature & 674 & $18,13 \%$ & $9,06 \%$ & 399 & $15,42 \%$ & $7,81 \%$ & 551 & $20,90 \%$ & $10,60 \%$ \\
\hline Decline & 384 & $14,91 \%$ & $5,94 \%$ & 493 & $20,91 \%$ & $11,24 \%$ & 224 & $17,30 \%$ & $1,97 \%$ \\
\hline T Statistics & T val. & \multicolumn{2}{|c|}{ Sig (2 tailed) } & T val. & \multicolumn{2}{|c|}{ Sig (2 tailed) } & T val. & \multicolumn{2}{|c|}{ Sig (2 tailed) } \\
\hline Growth - Mature & $-0,705$ & \multicolumn{2}{|c|}{0,482} & $-0,057$ & \multicolumn{2}{|c|}{0,955} & $-1,299$ & \multicolumn{2}{|c|}{0,195} \\
\hline Growth - Decline & 0,406 & \multicolumn{2}{|c|}{0,685} & $-2,508$ & \multicolumn{2}{|c|}{$0,012^{* *}$} & $-0,490$ & \multicolumn{2}{|c|}{0,580} \\
\hline Mature - Decline & 0,951 & \multicolumn{2}{|c|}{0,342} & $-1,153$ & \multicolumn{2}{|c|}{0,250} & 0,471 & \multicolumn{2}{|c|}{0,639} \\
\hline
\end{tabular}

Table 10 states the liquidity results of firms according to three different methods. While growth and mature firms are in need of cash to invest in profitable projects whose net present value is positive, decline firms are at the decision point that they either maintain the business or go into liquidation. Therefore, liquidity ratios will be higher at the decline stage. Hypothesis 4 which is related to liquidity and denoted by acid-test ratio is accepted for Anthony and Ramesh (1992) and Yonpae and Chen (2006) methods.

Table 10: Acid-Test Ratio

\begin{tabular}{|c|c|c|c|c|c|c|c|c|c|}
\hline $\begin{array}{l}\text { Classification } \\
\text { Method }\end{array}$ & \multicolumn{3}{|c|}{$\begin{array}{c}\text { Anthony and Ramesh } \\
\text { (1992) }\end{array}$} & \multicolumn{3}{|c|}{$\begin{array}{c}\text { Yonpae and Chen } \\
\text { (2006) }\end{array}$} & \multicolumn{3}{|c|}{$\begin{array}{l}\text { Dickinson } \\
\text { (2011) }\end{array}$} \\
\hline Stages & Obs. & Mean & Median & Obs. & Mean & Median & Obs. & Mean & Median \\
\hline Growth & 315 & 1,8649 & 0,9280 & 481 & 1,6075 & 0,9333 & 310 & 1,8667 & 0,9859 \\
\hline Mature & 674 & 1,8012 & 0,9957 & 399 & 1,6255 & 0,9885 & 551 & 1,8231 & 1,2656 \\
\hline Decline & 384 & 1,9556 & 1,3658 & 493 & 2,2934 & 1,3833 & 224 & 1,9629 & 1,0130 \\
\hline T Statistics & T val. & \multicolumn{2}{|c|}{ Sig (2 tailed) } & T val. & \multicolumn{2}{|c|}{ Sig (2 tailed) } & T val. & \multicolumn{2}{|c|}{ Sig ( 2 tailed) } \\
\hline Growth - Mature & 1,329 & \multicolumn{2}{|c|}{0,185} & 0,191 & \multicolumn{2}{|c|}{0,849} & 0,429 & \multicolumn{2}{|c|}{0,668} \\
\hline Growth - Decline & $-0,259$ & \multicolumn{2}{|c|}{0,796} & $-2,901$ & \multicolumn{2}{|c|}{$0,004 * * *$} & 1,004 & \multicolumn{2}{|c|}{0,318} \\
\hline Mature - Decline & $-2,107$ & \multicolumn{2}{|c|}{$0,036 * *$} & $-3,084$ & \multicolumn{2}{|c|}{$0,002 * * *$} & $-0,210$ & \multicolumn{2}{|c|}{0,834} \\
\hline
\end{tabular}

Growth stage can be characterized as a period when expected profits from investment opportunities increase and the need for financing will become even more felt. Since managers will use the generated cash to evaluate growth opportunities more effectively, these firms tend to finance the projects with foreign sources despite the high borrowing costs. Therefore, growth firms have the higher risk than the firms at the other stages. Financial leverage is used to measure the risk level in Table 11 and hypothesis 5 is accepted for all methods. 
Table 11: Financial Leverage

\begin{tabular}{|c|c|c|c|c|c|c|c|c|c|}
\hline \multirow{2}{*}{$\begin{array}{l}\begin{array}{l}\text { Classification } \\
\text { Method }\end{array} \\
\text { Stages }\end{array}$} & \multicolumn{3}{|c|}{$\begin{array}{c}\text { Anthony and Ramesh } \\
\text { (1992) }\end{array}$} & \multicolumn{3}{|c|}{$\begin{array}{l}\text { Yonpae and Chen } \\
\text { (2006) }\end{array}$} & \multicolumn{3}{|c|}{$\begin{array}{l}\text { Dickinson } \\
\text { (2011) }\end{array}$} \\
\hline & Obs. & Mean & Median & Obs. & Mean & Median & Obs. & Mean & Median \\
\hline Growth & 315 & 0,53 & 0,49 & 481 & 0,50 & 0,51 & 310 & 0,50 & 0,51 \\
\hline Mature & 674 & 0,53 & 0,43 & 399 & 0,58 & 0,43 & 551 & 0,44 & 0,39 \\
\hline Decline & 384 & 0,51 & 0,32 & 493 & 0,48 & 0,29 & 224 & 0,43 & 0,40 \\
\hline T Statistics & T val. & \multicolumn{2}{|c|}{ Sig (2 tailed) } & T val. & \multicolumn{2}{|c|}{ Sig (2 tailed) } & T val. & \multicolumn{2}{|c|}{ Sig (2 tailed) } \\
\hline Growth - Mature & 0,682 & \multicolumn{2}{|c|}{0,496} & 1,310 & \multicolumn{2}{|c|}{0,191} & 2,987 & \multicolumn{2}{|c|}{$0,003 * * *$} \\
\hline Growth - Decline & 6,959 & \multicolumn{2}{|c|}{$0,000 * * *$} & 7,445 & \multicolumn{2}{|c|}{$0,000 * * *$} & 0,556 & \multicolumn{2}{|c|}{0,580} \\
\hline Mature - Decline & 5,644 & \multicolumn{2}{|c|}{$0,000 * * *$} & 4,664 & \multicolumn{2}{|c|}{$0,000 * * *$} & $-2,934$ & \multicolumn{2}{|c|}{$0,004 * * *$} \\
\hline
\end{tabular}

\section{CONCLUDING REMARKS}

The theory of corporate life-cycle has been widely studied in a variety of disciplines and it is one of the key analysis to examine the economic conditions which is unique to the company since the 1970s. Recently, many accounting and finance studies use firm life cycle hypothesis to categorize and define companies more homogeneously in their analysis. In this study, we first aim to define the life cycle concept through explaining most common corporate life cycle stages classification methods. We demonstrate the most used variables such as sales growth, capital expenditures growth, firm age, dividend, cash flow profiles etc. in different techniques.

Our second motivation is to provide better results through comparing the three common methods for main financial variables at life cycle stages. We develop five hypotheses that are related to firm size, profitability, stock returns, liquidity and risk of the firms for three different stages. According to the results, Anthony and Ramesh (1992) method provides better results for the hypotheses which are presented in Table 12. Since cash flow based information is not value relevant than earnings, the results show major differences especially in Dickinson (2011) method.

Table 12: Hypotheses Results

\begin{tabular}{llccc}
\hline Hypotheses & Variables & $\begin{array}{c}\text { Anthony and Ramesh } \\
\mathbf{( 1 9 9 2 )}\end{array}$ & $\begin{array}{c}\text { Yonpae and Chen } \\
(\mathbf{2 0 0 6 )}\end{array}$ & $\begin{array}{c}\text { Dickinson } \\
\text { (2011) }\end{array}$ \\
\hline Firm Size (1) & Total Assets & Accepted & Accepted & Rejected \\
\hline Profitability (2) & Earnings per Share & Rejected & Rejected & Accepted \\
\hline Stock Returns (3) & Cumulative Returns & Accepted & Rejected & Accepted \\
\hline Liquidity (4) & Acid-Test Ratio & Accepted & Accepted & Rejected \\
\hline Risk (5) & Financial Leverage & Accepted & Accepted & Accepted \\
\hline
\end{tabular}

There are some limitations for this study. First of all, we have only examined the non-financial Turkish firms for a specified time. In addition, we have studied main financial ratios and three classification procedures in the analysis. Future studies may concentrate on different countries, periods, variables and classification techniques to robust the results. Future studies may also focus on the life cycle concept as a mediator variable to improve the perspectives for other accounting topics. 


\section{REFERENCES}

Adizes, I. 1979, "Organizational Passages-Diagnosing and Treating Lifecycle Problems of Organizations." Organizational Dynamics, 8(1), 325

Aharony, J., Falk, H. \& Yehuda, N. 2006, "Corporate Life Cycle and the Relative Value-Relevance of Cash Flow Versus Accrual Financial Information" Working Paper, Citeseer.

Anthony, J. H. \& Ramesh, K. 1992, "Association Between Accounting Performance Measures and Stock Prices: A Test of the Life-Cycle Hypothesis." Journal of Accounting and Economics, 15(2), 203-227.

Black, E. L. 1998a, "Life-Cycle Impacts on the Incremental Value-Relevance of Earnings and Cash Flow Measures." Journal of Financial Statement Analysis, 4, 40-57.

Black, E. L. 1998b, "Which is More Value-Relevant: Earnings or Cash Flows?" Working Paper, Available at SSRN 118089.

Chen, X., Yang, W. \& Huang, D. 2010, "Corporate Life Cycle and the Accrual Model: An Empirical Study Based on Chinese Listed Companies." Frontiers of Business Research in China, 4(4), 580-607.

DeAngelo, H., DeAngelo, L. \& Stulz, R. M. 2006, "Dividend Policy and the Earned/Contributed Capital Mix: A Test of the Life-Cycle Theory." Journal of Financial Economics, 81(2), 227-254.

Dickinson, V. 2011, "Cash Flow Patterns as a Proxy for Firm Life Cycle." The Accounting Review, 86(6), $1969-1994$.

Fama, E. F. \& French, K. R. 2001, "Disappearing Dividends: Changing Firm Characteristics or Lower Propensity to Pay?" Journal of Financial Economics, 60(1), 3-43.

Gaver, J. J. \& Gaver, K. M. 1993, "Additional Evidence on the Association Between the Investment Opportunity Set and Corporate Financing, Dividend, and Compensation Policies." Journal of Accounting and Economics, 16(1-3), 125-160.

Gort, M. \& Klepper, S. 1982, "Time Paths in the Diffusion of Product Innovations." The Economic Journal, 92(367), 630-653.

Grabowski, H. G. \& Mueller, D. C. 1975 "Life-Cycle Effects on Corporate Returns on Retentions." The Review of Economics and Statistics,

Hayn, C. 1995, "The information Content of Losses." Journal of Accounting and Economics, 20(2), 125-153.

Jaafar, H. \& Halim, H. A. 2015, "Refining the Firm Life Cycle Classification Method: A Firm Value Perspective." Journal of Economics, Business and Management, 4(2), 112-119.

Jain, B. A. \& Kini, O. 1999, "The Life Cycle of Initial Public Offering Firms." Journal of Business Finance \& Accounting, 26(9-10), $1281-1307$.

James, B. G. 1974, "The Theory of the Corporate Life Cycle." Long Range Planning, 7(2), 49-55.

Kallunki, J.-P. \& Silvola, H. 2008, "The Effect of Organizational Life Cycle Stage on the Use of Activity-Based Costing." Management Accounting Research, 19(1), 62-79.

Kotler, P. 2009, "Marketing Management: A South Asian Perspective:" Pearson Education, India.

Lev, B. \& Zarowin, P. (1999). "The Boundaries of Financial Reporting and How to Extend Them (Digest Summary)." Journal of Accounting Research, 37(2), 353-385.

Miller, D. \& Friesen, P. H. 1983, "Successful and Unsuccessful Phases of the Corporate Life Cycle." Organization Studies, 4(4), $339-356$.

Miller, D. \& Friesen, P. H. 1984, "A longitudinal Study of the Corporate Life Cycle." Management Science, 30(10), 1161-1183.

Mueller, D. C. 1972, "A Life Cycle Theory of the Firm." The Journal of Industrial Economics, 199-219.

Myers, S. C. 1977, "Determinants of Corporate Borrowing." Journal of Financial Economics, 5(2), 147-175.

Richardson, P. R. \& Gordon, J. R. 1980, "Measuring Total Manufacturing Performance." Sloan Manage. Rev.;(United States), 21(2).

Rink, D. R. \& Swan, J. E. 1979, "Product Life Cycle Research: A Literature Review." Journal of Business Research, 7(3), $219-242$.

Seifert, B. \& Gonenc, H. 2012, "Issuing and Repurchasing: The Influence of Mispricing, Corporate Life Cycle and Financing Waves." Journal of Multinational Financial Management, 22(3), 66-81.

Spence, A. M. 1979, "Investment Strategy and Growth in a New Market." The Bell Journal of Economics, 1-19.

Won, J. \& Ryu, S.-L. 2015, "Operational Efficiency and Firm Life Cycle in the Korean Manufacturing Sector." Paper Presented at the Current Research on Business VI. Proceedings of the 8th International Workshop, Jeju Island, Korea.

Yonpae, P. \& Chen, K. 2006, "The Effect of Accounting Conservatism and Life-Cycle Stages on Firm Valuation." Journal of Applied Business Research, 22(3), 75. 